\title{
Seasonal dry matter production of Lotus corniculatus in a dryland commercial sheep pastoral system
}

\author{
C.A. RAMIREZ-RESTREPO ${ }^{1}$, P.D. KEMP ${ }^{2}$, T.N. BARRY ${ }^{1}$ and N. LOPEZ- \\ VILLALOBOS ${ }^{1}$ \\ ${ }^{1}$ Institute of Veterinary, Animal and Biomedical Sciences, Massey University, Private Bag 11 222, \\ Palmerston North \\ ${ }^{2}$ Institute of Natural Resources, Massey University, Private Bag 11 222, Palmerston North
}

T.N.Barry@massey.ac.nz

\begin{abstract}
Lotus corniculatus (Birdsfoot trefoil, 'Grassland Goldie') may have a role in dryland pastoral systems in New Zealand, but there is little information available on its production under sheep grazing in these conditions. Dry matter (DM) production of $L$. corniculatus was measured monthly for 2 consecutive years in a systems approach experiment comparing it with perennial ryegrass (Lolium perenne)/white clover (Trifolium repens) pasture in the Wairarapa on the east coast of the North Island. The total DM produced for 2 years was 8.5 and $10.5 \mathrm{t} /$ ha for $L$. corniculatus compared with 7.3 and $9.9 \mathrm{t} /$ ha for pasture. Also, the moderate concentration of CT (18$29 \mathrm{~g} / \mathrm{kg} \mathrm{DM}$ ) in L. corniculatus has been shown to increase sheep productivity (Wang et al. 1996ab; Min et al. 1999, 2001). This production advantage, combined with improved sheep performance, supports the potential use of $L$. corniculatus as a specialist forage in dryland areas.
\end{abstract}

Key words: condensed tannins, perennial ryegrass, Lolium perenne, white clover, Trifolium repens, pasture.

\section{Introduction}

Lotus corniculatus (Birdsfoot trefoil, 'Grassland Goldie') is a perennial forage legume tolerant of low soil fertility, drought conditions, soil acidity and impeded drainage (Heinrichs 1970; Douglas \& Foote 1993), which normally limit survival of other legume species. Experimental evidence (Wang et al. 1996ab; Min et al. 1999, 2001; Ramírez-Restrepo et al. 2002) suggests that L. corniculatus is able to contribute to animal feed demands and environmental sustainability due to its seasonal forage production, high feeding value, and its moderate concentration of condensed tannins (CT) (Ramírez-Restrepo et al. 2003a,b). Research from glasshouse environments and small plots has shown that L. corniculatus maintains its quality during maturity and comparatively high yield production occurs during summer (Ayala 2001; Bologna et al. 1996). However, little is known about its production throughout consecutive years under grazing conditions in a dryland environment in New Zealand.

Thus, the objective of this study was to determine annual and seasonal dry matter (DM) production of L. corniculatus under grazing management over two consecutive years relative to perennial ryegrass/white clover pasture.

\section{Materials and methods}

Nine hectares of $L$. corniculatus were established in a moderate soil fertility on $6 / 3 / 2000$. The study was conducted from November 2000 to October 2002 at Massey University's Riverside farm, in the Wairarapa on the east coast of the North Island, New Zealand. Sowing rate was $20 \mathrm{~kg} / \mathrm{ha}$ of coated/inoculated seed and was sown at $10 \mathrm{~mm}$ depth with a cone-type plot seeder equipped with double disc openers set 150 $\mathrm{mm}$ apart. Forage DM yields were calculated at monthly intervals under grazing from November 2000 to October 2002 using a systems approach. In this system, effects on plant production and effects of feeding upon sheep productivity (data not shown) were measured simultaneously. Similar areas of adjoining perenial ryegrass/white clover pasture were used as the control.

Patterns of DM production for both $L$. corniculatus and pasture were measured using two techniques. Firstly, we selected, marked and cut to ground level 8 random quadrats $\left(0.180 \mathrm{~m}^{2}\right)$ in a specific area to be grazed approximately 30 days later. To give an estimate of growth over a fixed period, a further 8 random quadrats in the same area were selected and protected with exclosure cages measuring 1.4 x $0.9 \mathrm{~m}$, 
which were sampled 30 days later before grazing commenced. Secondly, the post-grazing pasture mass was measured from 8 quadrats using cuts at ground level. This area was then allowed to regrow and was resampled from 8 different exclosure areas 30 days later. This measurement gave a second estimate of herbage growth rate. All plant samples were washed and dried overnight $(16 \mathrm{~h})$ in a forced-air oven (Contherm; Thermotec 2000; New Zealand) at $80{ }^{\circ} \mathrm{C}$. The initial dates of sampling were staggered so that growth could be studied in successive overlapping periods of 30 days (Davies 1993).

The remaining areas of $L$. corniculatus and perennial ryegrass/white clover pasture were grazed by commercial flocks of sheep and cattle. Additionally, pasture paddocks were mechanically topped during summer to remove reproductive stem material, thus encouraging vegetative growth. During winter 2001, the L. corniculatus was sprayed with herbicide to control grasses (haloxyfop (a.i.), $300 \mathrm{~g} / \mathrm{ha}$ ). Broadleaved weeds were controlled during the second wet season using $375 \mathrm{~g} / \mathrm{ha}$ paraquat (a.i.) plus $225 \mathrm{~g} / \mathrm{ha}$ diquat (a.i.) and metribuzin (a.i.) $700 \mathrm{~g} / \mathrm{ha}$.

Annual rainfall (Nov Oct) was greater during the second year (967 v $1072 \mathrm{~mm})$. The summer/autumn season (Jan-April) was drier during the first year than the second, accounting for $187 \mathrm{~mm}(19 \%)$ and $275 \mathrm{~mm}(26 \%)$ of the annual rainfall, respectively (Figure 1), and rainfall was about $4 \mathrm{~mm}$ below the 50year average (New Zealand Metereological Service 1983).

\section{Results and discussion}

Over a 2 year period, 1536 forage samples were collected. The two DM measurement techniques gave

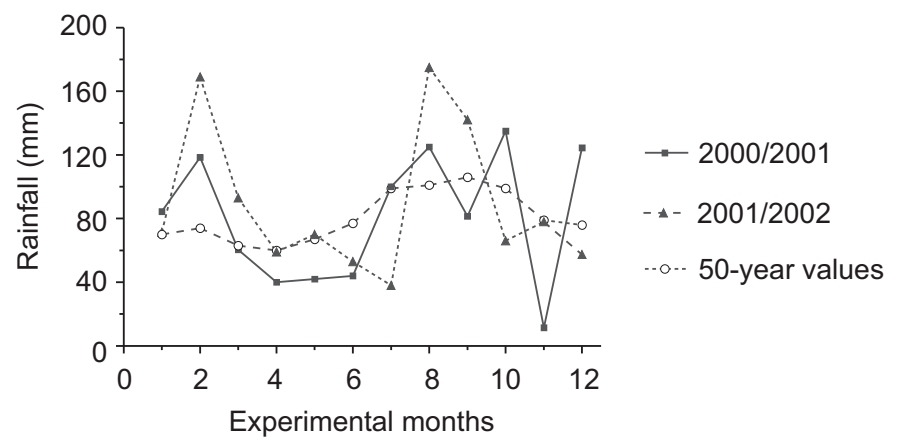

Figure 1 Mean rainfall during two consecutive years at Massey University's Riverside farm in the Wairarapa, on the east coast of the North Island, New Zealand, compared with the 50-year mean values (New Zealand Metereological Service 1983). similar results, so the mean of both techniques is reported for all data. L. corniculatus was greater than perennial ryegrass/white clover pasture in first $(8.5 \pm$ $0.21 \mathrm{v} 7.3 \pm 0.21 \mathrm{t} \mathrm{DM} / \mathrm{ha})$ and second seasons $(10.5$ $\pm 0.25 \mathrm{v} 9.9 \pm 0.20 \mathrm{t} \mathrm{DM} / \mathrm{ha})$. The significance of the differences could not be calculated because this was a systems experiment without true replication. The extra production from $L$. corniculatus predominantly occurred over the summer/autumn period (Figure 2).

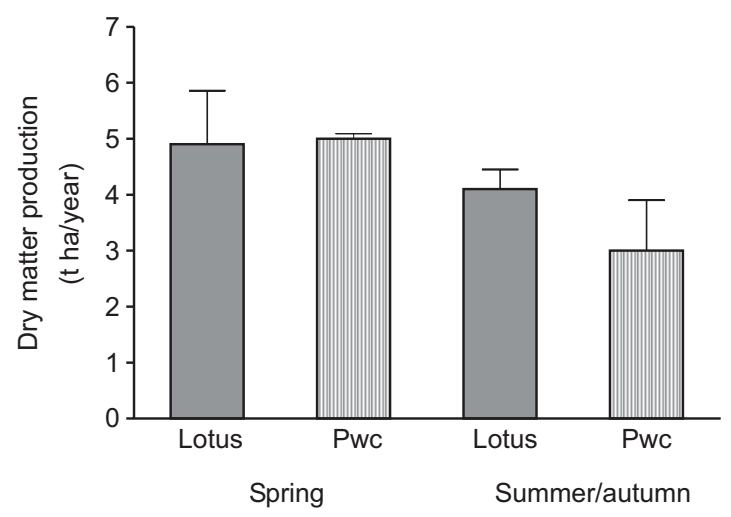

Figure 2 Mean cumulative seasonal dry matter (DM) production of Lotus corniculatus ('Grasslands Goldie') and perennial ryegrass/white clover pasture (Pwc) in a dryland farming system averaged over two years (2001 and 2002). (Vertical bars represent one standard error of the mean).

Monthly patterns of DM production were similar for L. corniculatus and pasture (Figure 3), with the principal production advantage of $L$. corniculatus occurring during lower summer/autumn rainfall in 2000-2001 rather than in the wet conditions of the 2001-2002 summer/ autumn (Figure 3 ). The negative growth rates for some periods in late autumn and winter were due to low temperatures, resulting in L. corniculatus and pasture growth that was occurring more slowly than the rate of senescence.

DM production of both forages was similar in spring, but L. corniculatus had higher yields during summer/autumn and better feeding value, and higher digestibility and metabolisable energy concentration (Ramírez-Restrepo et al. $2003 \mathrm{ab}$ ) than the perennial ryegrass/ white clover pasture, throughout 2 


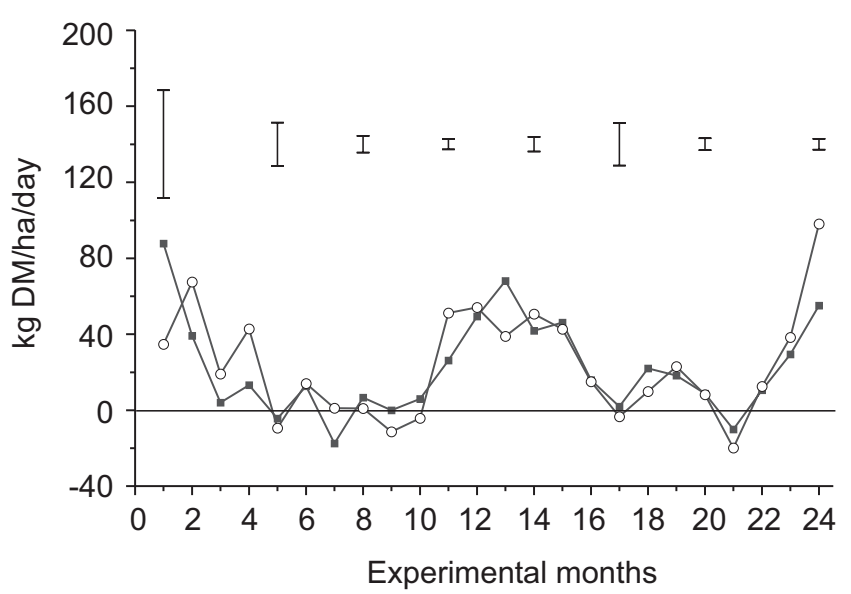

Figure 3 Monthly growth rates of Lotus corniculatus ('Grasslands Goldie') ( $O$ ) and of perennial ryegrass/white clover pasture ( $\mathbf{\square})$ grown in the Wairarapa on the east coast of the North Island, New Zealand. Data collected from November 2000 to October 2002. Bars indicate pooled standard error.

consecutive years. This suggests $L$. corniculatus could be used productively in a commercial sheep dryland farming system.

\section{Conclusions}

Lotus corniculatus produced similar dry matter yield to perennial ryegrass/white clover pasture during spring and was more productive during summer/ autumn. We recommend that the best use of DM produced by L. corniculatus under a dryland farming system is during the mating season in late summer/ autumn, as it improved reproductive efficiency (16\% units) and wool production ( $8 \%$ ) of ewes, as well as lamb viability from conception to weaning, particlurly in years with exceptionally dry autumn periods (Ramírez-Restrepo et al. 2003b). A second use is to feed $L$. corniculatus during spring to simultaneously increase body growth in lambs $(26 \%)$ and both ewe and lamb wool production, with reduced pre-lambing anthelmintic drenching (Ramírez-Restrepo et al. 2002; Ramírez-Restrepo et al. 2003a).

\section{ACKNOWLEDGEMENTS}

We acknowledge Meat \& Wool Innovations for financial support of Massey L. corniculatus work in the Wairarapa. The New Zealand Ministry of Foreign Affairs and Trade, Massey University and the Colombian Agriculture Research Agency (CORPOICA) are acknowledged for provision of scholarship support to Carlos A. Ramírez-Restrepo.

\section{REFERENCES}

Ayala, W. 2001. Defoliation management of birdsfoot trefoil (Lotus corniculatus L.) PhD thesis. Massey University, Palmerston North, New Zealand.

Barry, T.N.; Kemp, P.D.; Ramírez-Restrepo, C.A.; López-Villalobos, N. 2003. Sheep production and agronomic performance of Lotus corniculatus under dryland farming. Proceedings of the New Zealand Grassland Association 65: 109-115.

Bologna J.J.; Rowarth, J.S.; Fraser, T.J.; Hill, G.D. 1996. Management of birdsfoot trefoil (Lotus corniculatus L.) pasture for productivity and persistence. Proceedings of the Agronomy Society of New Zealand 26:17-21.

Davies, A. 1993. Tissue turnover in the sward. pp. 183215. In: Sward measurement handbook. Second edition. Eds. Davies, A.; Baker, R.D.; Grant, S.A.; Laidlaw, A.S. The British Grassland Society, U.K.

Douglas, G.B.; Foote, A.G. 1993. Growth of sheep's burnet and two dryland legumes under periodic mob-stocking with sheep. New Zealand Journal of Agricultural Research 36: 393-397.

Heinrichs, D. H. 1970. Flooding tolerance of legumes. Canadian Journal of Plant Science 50: 435-438.

Min, B.R.; Fernandez, J.M.; Barry, T.N.; McNabb, W.C.; Kemp, P.D. 2001. The effect of condensed tannins in Lotus corniculatus upon reproductive efficiency and wool production in ewes during autumn. Animal Feed Science and Technology 92: 185-202.

Min, R.B.; McNabb, W.C.; Barry, T.N.; Kemp, P.D.; Waghorn, G.C.; McDonald, M.F. 1999. The effect of condensed tannins in Lotus corniculatus upon reproductive efficiency and wool production in sheep during late summer and autumn. Journal of Agriculture Science, Cambridge 132: 323-334.

New Zealand Metereological Service. 1983. Summaries of climatological observations to 1980. New Zealand Metereological Service Miscellaneous Publication 177.

Ramírez-Restrepo, C.A.; Barry, T.N.; López-Villalobos, N.; Kemp, P.D.; Pomroy, W.E.; McNabb, W.C.; Harvey, T.G.; Shadbolt, N.M. 2002. Use of Lotus corniculatus to increase sheep production under commercial dryland farming conditions without the use of anthelmintics. Proceedings of the New Zealand Society of Animal Production 62: 177178.

Ramírez-Restrepo, C.A.; Barry, T.N.; López-Villalobos, N.; Kemp, P.D.; McNabb, W.C. 2003a. Use of 
Lotus corniculatus containing condensed tannins to increase lamb and wool production under commercial dryland farming conditions without the use of anthelmintics. Animal Feed Science and Technology. In press.

Ramírez-Restrepo, C.A.; Barry, T.N.; López-Villalobos, N.; Kemp, P.D.; Harvey, T.G. 2003b. Use of Lotus corniculatus containing condensed tannins to increase reproductive efficiency in ewes under commercial dryland farming conditions. Animal Feed Science and Technology. In press.
Wang, Y.; Douglas, G.B.; Waghorn, G.C.; Barry, T.N.; Foote, A.G. 1996a. Effect of condensed tannin upon lactation performance in ewes. Journal of Agricultural Science, Cambridge 126: 353-362.

Wang, Y.; Douglas, G.B.; Waghorn, G.C.; Barry, T.N.; Foote, A.G.; Purchas, R.W. 1996b. Effect of condensed tannin upon the performance of lambs grazing Lotus corniculatus and lucerne (Medicago sativa). Journal of Agricultural Science, Cambridge 126: 87-98. 